\title{
The Anadromous Hickory Shad (Clupeiformes: Clupeidae, Alosa mediocris [Mitchill 1814]): Morphometric and Meristic Variation
}

Jordan P. Smith, Department of Biology, East Carolina University, Greenville, NC 27858

Michael S. Brewer, Department of Biology, East Carolina University, Greenville, NC 27858

Roger A. Rulifson, Department of Biology, East Carolina University, Greenville, NC 27858

Author contact: rulifsonr@ecu.edu

Abstract

The anadromous Hickory Shad Alosa mediocris (Mitchill, 1814) (Clupeiformes: Clupeidae) is reviewed, specifically regarding morphometric and meristic variation. Despite its long history as recognized species, few descriptions of Hickory Shad morphometric and meristic characters exist in the literature. Most authors of the historic literature have failed to provide capture location for specimens, analyze large numbers of Hickory Shad, or document how morphometric and meristic characters of the species vary spatially. To address this information gap, a total of 717 mature Hickory Shad were collected from 23 different locations in Maryland, Delaware, Virginia, North Carolina, South Carolina, Georgia, and Florida using electroshocking, gill net, or rod and reel. All specimens were frozen, thawed, and 17 morphometric characters and four meristic characters were examined; a random subset $(n=463)$ were analyzed for an additional four meristic counts of gill rakers. Overall specimens ranged from 206-389 mm SL with a mean \pm SD of $278.41 \pm 27.69 \mathrm{~mm}, 232-435 \mathrm{~mm}$ FL with a mean of $310.98 \pm 30.35 \mathrm{~mm}$, and 272-508 $\mathrm{mm}$ TL with a mean of $365.62 \pm 35.52 \mathrm{~mm}$. The linear relationships between FL and TL, and FL and SL, were investigated and found to be: TL $=1.169 * \mathrm{FL}+1.660(\mathrm{n}=705$, $\left.r^{2}=0.995\right)$ and $S L=0.909 * F L-4.274\left(n=717, r^{2}=0.992\right)$. Substantial differences in character means for many morphometric measurements were found between male and female specimens, suggesting strong sexual dimorphisms relating to shape. However, meristic characters did not show differences in character means by sex. No one morphometric measurement could distinguish Hickory Shad from other morphologically similar clupeids, but the meristic count of gill rakers on the lower limb of the first arch were important to separate Hickory Shad (19-22) from American Shad A. sapidissima (Wilson, 1811), Alewife A. pseudoharengus (Wilson, 1811), and Blueback Herring A. aestivalis (Mitchill, 1814).

\section{Introduction}

No published study has examined and described an extensive set of morphometric and

37 Clupeidae). The initial description of Hickory Shad lacked some critical information, indicating that this was a species unknown to the system and proceeded to describe it from "fresh 
examined. It is possible that the description could have been based from one or several individuals. We speculate that the likely watershed from which Mitchill collected his

42 specimen(s) was the Hudson River due to its close proximity to Columbia University.

43 Few records exist of Mitchill's early attempts to describe New York fauna, including $A$.

44 mediocris. Perhaps Professor Mitchill took students to the shores of the Hudson River to observe

45 fauna from pulling small seines; unless more early writings of Professor Mitchill are discovered,

46 the locations and manner of these ichthyological collections will remain unknown. One or more

47 of those specimens collected was an undescribed species of "Shad", which he presumably took

48 back to his laboratory for examination and decided the specimen(s) fit within the family

49 Clupeidae. Mitchill proceeded to designate the species Clupea mediocris - the "Staten Island

50 Herring”. In a presumably similar manner, Mitchill also described 11 other new species during

51 that era (including what is now known as Alosa aestivalis (Mitchill, 1814), the Blueback

52 Herring) although all 12 new "Mitchillian" species, including the current-day Hickory Shad and

53 Blueback Herring, were placed in different genera by subsequent authorities [1].

55 description of the anatomical features. Mitchill [2] included basic descriptions of the fish shape,

56 color, size, and meristic counts for branchiostegal, pectoral, ventral, anal, dorsal, and caudal fin

57 rays, but he did not include any information on morphological measurements or ratios of size

58 between various body features. Interestingly, many researchers describing the few characteristics

59 of this species did so citing other investigators, who in turn cited Mitchill [2]. Therefore, little

60 additional meristic or morphological information has been recorded for the species since the

61 original description, over 200 years ago. 
In addition, no record can be located of the holotype, nor where or when the specimen

63 was collected. During this time of budding taxonomy in America, it was neither common nor

64 required to keep holotype specimens for newly described species. Other taxonomists after

65 Mitchill revised the taxonomic status of the Hickory Shad. Notably, the genus Alosa was divided

66 into three genera by Regan [3] in 1917: Alosa, Caspialosa, and Pomolobus; the Hickory Shad

67 was classified under the genus Pomolobus along with the Alewife and the Blueback Herring [4].

68 Later work by Bailey [5] and Svetoviodov [6] led to synonymizing the genera Pomolobus and

69 Caspialosa with the genus Alosa, thereby changing the scientific name of Hickory Shad from

70 Pomolobus mediocris to A. mediocris (Mitchill, 1814) [4].

71 Mansueti [7] examined the hypothesis that the Hickory Shad might be a hybrid between

72 the American Shad Alosa sapidissima (Wilson, 1811) and one of the River Herrings, the Alewife

73 Alosa pseudoharengus (Wilson, 1811) or the Blueback Herring A. aestivalis. He concluded that

74 hybridization was unlikely and "not substantiated by any reliable evidence" [7]. Around this

75 time, a few fish culturists experimented in hatcheries and actively pursued creating hybrids

76 involving Hickory Shad and River Herring, though none of these attempts were successful [7].

77 The objective of this manuscript is to fully describe the various anatomical features,

78 including meristic counts and morphological measurements, of the Hickory Shad across its

79 range. The Hickory Shad is considered an understudied fish species though it spawns in rivers on

80 the United States Eastern Seaboard from the Schuylkill River in the Delaware River watershed

81 [8] to the St. Johns River in Florida [9]. The northern range limit of Hickory Shad spawning

82 populations is not precisely known; early authors hypothesized spawning as far north as Maine

83 [10]. A spawning population is suspected in Wethersfield Cove in the Connecticut River near

84 Wethersfield, Connecticut, but evidence is lacking; adult Hickory Shad have been collected from 
85 that area during spring (Ken Sprankle, USFWS, personal communication). Rulifson [11]

86 reported that Connecticut is the northernmost state having a presence of Hickory Shad based on

87 responses to questionnaires by respective state fisheries biologists. It is possible some of these

88 northern accounts of Hickory Shad are either misidentifications with morphologically similar

89 species, such as the American Shad A. sapidissima, or possibly wandering Hickory Shad

90 collected in bays or the Atlantic Ocean, but not actively spawning. The Hickory Shad is a

91 schooling species of the family Clupeidae and utilizes the life history strategy of anadromy,

92 entering coastal freshwater between February and June to spawn; the higher latitudes correspond

93 to later dates of entry into freshwater [12].

$94 \quad$ Relatively few authors have included morphometric and meristic values for Hickory Shad

95 [13], [14], [15], [10], [16], [17], [18] but none investigated how these characters vary spatially.

96 Most previous studies fail to provide capture location(s) for the specimens examined and cover

97 many fewer characters than the present study. Furthermore, some authors provide only one value

98 for various meristic counts and morphometric measurements, when in reality there is often

99 considerable variation. No published study has described Hickory Shad specimens across such a

100 large latitudinal gradient, covering the majority of the species range. Similar studies have been

101 undertaken for the American Shad [19], Alewife, and Blueback Herring [20].

102 Historically, morphometric and meristic analyses of fish have been valuable tools for

103 early ichthyologists and naturalists alike [21]. Starting in 1894, the Royal Society of the United

104 Kingdom created the "Committee for Conducting Statistical Inquiries into the Measurable

105 Characters of Plants and Animals." One of the committee's chief tasks was to investigate

106 morphometric variation in Atlantic Herring Clupea harengus (Linneaus, 1758) [22]. Analysis of 
morphological and meristic characters of fish is straightforward, cost-efficient, and an often-used tool to identify and differentiate fish species, stocks, and populations [23].

\section{Methods}

Hickory Shad specimens were collected during the 2016 and 2017 spawning runs from

113 the Susquehanna and Patapsco rivers, Maryland; the Nanticoke River, Delaware; the

114 Rappahannock, Appomattox, and James rivers, Virginia; the Chowan River headwaters

115 (Meherrin, Nottaway, and Blackwater), also in Virginia; the Roanoke, Cashie, Pungo, Pamlico,

116 Tar, Neuse, New, and Cape Fear rivers, North Carolina; Pamlico Sound, also in North Carolina;

117 the Waccamaw and Santee rivers, South Carolina; the Altamaha River, Georgia, and the St.

118 Johns River, Florida (Table 1). In addition, a few specimens $(\mathrm{n}=5)$ were obtained from the

119 Atlantic Ocean close to shore, near Wrightsville Beach, North Carolina. Relative location of

120 rivers as well as collection sites are depicted in Figure 1. All specimens were collected from the

121 different locations by recreational angling (i.e., rod and reel), gill net, or electrofishing.

122 Specimens from rivers outside of North Carolina were collected and donated to this study by the

123 respective state or federal fisheries agencies. North Carolina fish came from the North Carolina

124 Wildlife Resources Commission (NCWRC) or the North Carolina Division of Marine Fisheries

125 (NCDMF). Additional sampling was conducted by the Rulifson Lab with electrofishing and rod 126 and reel (NC Scientific Collection Permit Number 17-SFC00133; East Carolina University AUP 127 \#D330). 
Table 1. List of states and river (north to south), sex, and total number of Hickory Shad collected in 2016 and 2017.

\begin{tabular}{|c|c|c|c|c|c|}
\hline \multirow[b]{2}{*}{ State } & \multirow[b]{2}{*}{ River } & \multicolumn{2}{|c|}{ Sex } & \multirow[b]{2}{*}{ Unknown } & \multirow[b]{2}{*}{ Total } \\
\hline & & Female & Male & & \\
\hline Maryland & Susquehanna R. & 13 & 9 & & 22 \\
\hline Maryland & Patapsco R. & 11 & 39 & & 50 \\
\hline Delaware & Nanticoke R. & 16 & 6 & & 22 \\
\hline Virginia & Rappahannock R. & 23 & 21 & 3 & 47 \\
\hline Virginia & Appomattox R. & 25 & 25 & & 50 \\
\hline Virginia & James R. & 26 & 37 & 2 & 65 \\
\hline Virginia & Chowan R. (Meherrin) & & 1 & & 1 \\
\hline Virginia & Chowan R. (Nottaway) & 7 & 11 & & 18 \\
\hline Virginia & Chowan R. (Blackwater) & 13 & 11 & 1 & 25 \\
\hline North Carolina & Roanoke R. & 21 & 23 & & 44 \\
\hline North Carolina & Cashie R. & 17 & 17 & & 34 \\
\hline North Carolina & Pamlico Sound & 63 & 29 & 2 & 94 \\
\hline North Carolina & Pungo R. & & 2 & 1 & 3 \\
\hline North Carolina & Pamlico R. & 39 & 24 & 1 & 64 \\
\hline North Carolina & Tar R. & 31 & 20 & 1 & 52 \\
\hline North Carolina & Neuse R. & 14 & 30 & 3 & 47 \\
\hline North Carolina & New R. & 2 & 2 & 6 & 10 \\
\hline North Carolina & Atlantic Ocean* & 3 & & 2 & 5 \\
\hline North Carolina & Cape Fear R. & 5 & 13 & & 18 \\
\hline South Carolina & Waccamaw R. & 7 & & & 7 \\
\hline South Carolina & Santee R. & 2 & 4 & & 6 \\
\hline Georgia & Altamaha R. & 26 & 4 & & 30 \\
\hline \multirow[t]{2}{*}{ Florida } & St. Johns R. (Wekiva) & 1 & 2 & & 3 \\
\hline & & 365 & 330 & 22 & 717 \\
\hline
\end{tabular}

*denotes non-river or sound sampling location

Figure 1. Map showing relative location of rivers included in this study as well as collection sites of Hickory Shad. Revised after Melvin et al. [28].

Initially all specimens were frozen in water to minimize freezer burn and fin breakage,

136 and then eventually transferred to the Rulifson Lab at East Carolina University (ECU) for

137 examination. Once received or collected, fish were identified to species based on projection of

138 the lower jaw beyond the maxilla (as opposed to the American Shad, for which the lower jaw 
139 inserts into a slot in the maxilla), weighed to the nearest $0.01 \mathrm{~g}$, bagged individually without

140 water, and given a unique identification number. After this step the fish were placed in freezers (-

$14120^{\circ} \mathrm{C}$ or $-0^{\circ} \mathrm{C}$ ) on the ECU campus until analysis. Specimens were removed from the freezer and

142 slowly allowed to thaw. A small tissue sample was taken from the dorsal fin, which was then

143 placed in $95 \%$ ethanol $(\mathrm{ETOH})$ and stored in a $-80^{\circ} \mathrm{C}$ freezer for later genetic analysis.

145 recorded generally following the methods outlined by Hubbs and Lagler [24]. All measurements

146 were straight line distances from point to point on the left side of the body unless there was

147 physical damage: standard length (SL) -- distance between most anterior portion of the head

148 (lower jaw) to the last vertebrae; fork length (FL) -- the distance between the lower jaw to the

149 fork of the caudal tail; total length (TL) -- the greatest distance between lower jaw and end of

150 caudal fin when the caudal rays are pinched together; lower lip to nose (LLN) -- the distance of

151 the projecting lower jaw to maxilla; snout to anal length (SAL) -- the distance between lower jaw

152 and the anus; body depth (BD) -- greatest depth distance between anterior to dorsal fin and

153 anterior of the ventral fin; head length (HL) -- the distance from lower jaw to the most distant

154 point of the operculum (including membrane); eye length (EL) -- the greatest distance of the

155 orbit; snout length (SNL) -- the distance from the most anterior point of the upper lip to the

156 anterior margin of the orbit; head width (HW) -- the distance (width) across the head where the

157 preopercle ends; interorbital width (IOW) -- distance between the eyes at the top of the cranium;

158 maxillary length (ML) -- the distance from the tip of the upper jaw to the distal end of the

159 maxillary; fin length dorsal base (FLD) -- the greatest distance of the structural base between the

160 origin and insertion of the dorsal fin when the fin is erect; fin length anal base (FLA) -- the

161 greatest distance of the structural base between the origin and insertion of the anal fin when the 
162 fin is erect; longest ray dorsal fin (LRD) -- the distance from the structural base of the dorsal fin

163 to the tip of the longest ray; longest ray pectoral fin (LRP) -- distance from the structural base of

164 the pectoral fin to the tip of the longest ray; longest ray ventral (pelvic) fin (LRV) -- distance

165 from the structural base of the ventral fin to the tip of the longest ray; longest ray anal fin (LRA)

166 -- distance from the structural base of the anal fin to the tip of the longest ray when the fin is

167 erect. A Hickory Shad illustration (Figure 2) depicts how most morphometric measurements

168 were taken. IOW and HW were omitted on the illustration since they are width measurements

169 and cannot be accurately depicted. The standard length, total length, and snout-to-anal length

170 were measured to the nearest mm; all other measurements were taken by using Fisherbrand

171 "Traceable" digital calipers (model number 06-644-16) to the nearest $0.01 \mathrm{~mm}$.

Table 2. Morphometric measurements and meristic counts analyzed, and acronyms used in this study.

\begin{tabular}{lclc}
\hline Morphometric & Acronym & Meristic & Acronym \\
\hline Standard Length & SL & Posterior Ventral Scutes & PVS \\
Fork Length & FL & Anterior Ventral Scutes & AVS \\
Total Length & TL & Scale Rows & SR \\
Lower Lip-Nose & LLN & Longitudinal Scale Rows & LSR \\
Snout-to-Anal Length & SAL & Left Gill Raker Upper & L-GRU \\
Body Depth & BD & Right Gill Raker Upper & R-GRU \\
Head Length & HL & Left Gill Raker Lower & L-GRL \\
Eye Length & EL & Right Gill Raker Lower & R-GRL \\
Snout Length & SNL & & \\
Head Width & HW & & \\
Interorbital Width & IOW & & \\
Maxillary Length & ML & & \\
Fin Length-Dorsal Base & FLD & & \\
Fin Length-Anal Base & FLA & & \\
Longest Ray Dorsal Fin & LRD & & \\
Longest Ray Left Pectoral Fin & LRP & \\
Longest Ray Left Ventral Fin & LRV & \\
Longest Ray Anal Fin & LRA & & \\
\hline
\end{tabular}


173 Figure 2. Hickory Shad illustration showing how morphometric measurements were taken.

174 Reproduced from Whitehead [34].

External meristic counts were taken on the left side of the body, unless there was damage:

177 post ventral (pelvic) scutes (PVS) -- count of scutes from the end of the ventral fin to the anus;

178 anterior ventral scutes (AVS) -- count of scutes from the beginning of the operculum to the

179 ventral fin, including the scute straddling the ventral fins; scale rows (SR) -- count of scales

180 along the lateral line, beginning at the upper angle of the operculum and terminating at the end of

181 the hypural plate as determined with a crease in the caudal peduncle by folding the tail; and

182 longitudinal scale rows (LSR) -- count of scales from the origin of the dorsal fin to the origin of

183 the ventral fin. A random subset of specimens $(n=463)$ were analyzed for an additional four

184 internal meristic counts, including the left and right gill rakers of the upper first arch (L-GRU, R-

185 GRU) -- count of all gill rakers on the upper arch of first gill raker, not including the raker

186 straddling the angle; and left and right gill rakers lower (L-GRL, R-GRL) -- count of all first arch

187 gill rakers from the raker straddling the angle to the end, regardless of size.

External meristic characters including the scale rows between the upper angle of gill

189 opening and base of caudal fin, longitudinal scale rows between origin of ventral fin and origin

190 of dorsal fin, post-ventral scutes, and anterior-ventral scutes, were all counted from the freshly-

191 thawed specimens.

To the best of our knowledge, there are no references in the literature detailing specific

193 methods for counting scutes of clupeids. We chose to divide the scute count into two -- anterior

194 and posterior -- of the ventral fin following Smith [17], though Nichols [26] and Melvin et al.

195 [19] chose to count total scutes for American Shad. All scutes were counted, regardless of size,

196 from where the ventral surface reaches the operculum posterior to the anus. Special care was 
197 given to check for scutes obscured by the anus in all fish, specifically ripe females. Occasionally

198 scales near the scutes had to be removed to fully expose all scutes, and then counts were obtained

199 with the aid of a probe.

200 After external morphometric measurements and meristic counts were completed, fish

201 were then dissected to remove the gonads, which were weighed to the nearest $0.01 \mathrm{~g}$. Sex was

202 determined for each specimen based on visual inspection of the gonad. Once features of each

203 specimen were recorded, the data were compiled into one Microsoft Excel file for analyses.

204 Sample sizes for each state, watershed, and capture location were not uniform, nor were

205 the number of males and females the same, due to the various collection methods and availability

206 at the time of collection. In addition, the number of fish analyzed for each character was not

207 always equal because some of the specimens were damaged necessitating the omission of one or

208 more characters. Also the timing of the collection for each watershed was not standardized;

209 spawning often started prior to the typical timeline for state agency spring sampling. The

210 morphometric and meristic data presented here are from frozen and thawed -- not fresh --

211 Hickory Shad and for purposes of the analyses we assumed that any bias caused by this process

212 was equal across all specimens.

214 Results

Overall 717 Hickory Shad were analyzed for 17 morphometric measurements and four

216 meristic characters from 23 different rivers and estuaries in Maryland, Delaware, Virginia, North

217 Carolina, South Carolina, Georgia, and Florida following the methods outlined above. Results of

218 descriptive statistics for all locations combined, separated by sex, for all measurements and

219 counts are presented in Table 3. Results for each individual river and combined sex can be found 
220 in Table 4. The random subset of specimens $(n=463)$ analyzed for four internal meristic gill

221 raker counts showed that Hickory Shad had between 8-11 rakers on L-GRU, 8-12 rakers on R-

222 GRU, and 19-22 rakers on both L-GRL and R-GRL.

223

Table 3. Descriptive data of morphometric and meristic characters for female and male specimens of Hickory Shad. See text for descriptions of each measurement or count. All measurements given in mm.

\begin{tabular}{|c|c|c|c|c|c|c|c|c|c|c|c|}
\hline \multicolumn{6}{|c|}{ Female } & \multicolumn{6}{|c|}{ Male } \\
\hline Character & Range & Mean & SD & $\% \mathrm{SL}$ & $\mathbf{n}$ & Character & Range & Mean & SD & $\% \mathrm{SL}$ & $\mathbf{n}$ \\
\hline SL & $229-389$ & 292.41 & 26.09 & - & 365 & SL & $206-344$ & 264.62 & 20.63 & - & 330 \\
\hline FL & $260-435$ & 326.36 & 28.57 & 111.61 & 365 & FL & $232-382$ & 295.81 & 22.64 & 111.78 & 330 \\
\hline $\mathrm{TL}$ & $306-508$ & 383.36 & 33.55 & 131.10 & 364 & $\mathrm{TL}$ & $272-444$ & 347.67 & 26.48 & 131.38 & 326 \\
\hline LLN & $2.44-7.90$ & 3.93 & 0.73 & 1.34 & 365 & LLN & $2.39-7.39$ & 3.60 & 0.54 & 1.36 & 327 \\
\hline SAL & $172-289$ & 218.99 & 20.26 & 74.89 & 364 & SAL & $155-251$ & 197.51 & 15.45 & 74.64 & 330 \\
\hline BD & $65.74-134.89$ & 91.44 & 13.32 & 31.27 & 365 & BD & $60.70-105.09$ & 79.03 & 7.46 & 29.86 & 329 \\
\hline HL & $64.73-108.43$ & 81.40 & 6.96 & 27.84 & 364 & HL & $58.86-93.96$ & 74.72 & 5.99 & 28.24 & 329 \\
\hline EL & $11.82-19.60$ & 14.80 & 1.26 & 5.06 & 363 & EL & $11.53-18.59$ & 13.96 & 1.16 & 5.28 & 330 \\
\hline SNL & $15.93-27.84$ & 20.75 & 1.84 & 7.10 & 363 & SNL & $15.13-24.76$ & 19.07 & 1.63 & 7.21 & 330 \\
\hline HW & $23.67-47.07$ & 31.33 & 3.38 & 10.71 & 363 & HW & $21.87-37.11$ & 28.45 & 2.53 & 10.75 & 330 \\
\hline IOW & $10.38-20.90$ & 14.52 & 1.77 & 4.96 & 364 & IOW & $9.56-20.75$ & 13.35 & 1.60 & 5.05 & 329 \\
\hline ML & $26.51-41.90$ & 33.98 & 2.52 & 11.62 & 362 & ML & $25.38-37.15$ & 31.51 & 2.18 & 11.91 & 330 \\
\hline FLD & $33.97-63.41$ & 63.41 & 4.80 & 21.69 & 365 & FLD & $29.66-52.89$ & 39.77 & 3.74 & 15.03 & 329 \\
\hline FLA & $37.80-68.23$ & 49.00 & 4.65 & 16.76 & 363 & FLA & $32.43-62.17$ & 44.65 & 4.15 & 16.87 & 328 \\
\hline LRD & $29.88-55.12$ & 39.77 & 3.99 & 13.60 & 364 & LRD & $24.63-45.91$ & 36.23 & 3.32 & 13.69 & 327 \\
\hline LRP & $43.10-77.09$ & 55.42 & 5.32 & 18.95 & 363 & LRP & $38.84-64.67$ & 50.83 & 4.45 & 19.21 & 330 \\
\hline LRV & $23.76-46.09$ & 34.90 & 3.29 & 11.93 & 362 & LRV & $23.80-39.84$ & 31.97 & 2.88 & 12.08 & 330 \\
\hline LRA & $14.61-26.59$ & 19.74 & 2.33 & 6.75 & 360 & LRA & $13.13-23.60$ & 17.99 & 1.89 & 6.80 & 326 \\
\hline $\mathrm{SR}$ & $49-56$ & 51.65 & 1.23 & & 349 & $\mathrm{SR}$ & $49-56$ & 51.60 & 1.12 & & 316 \\
\hline LSR & $15-19$ & 17.81 & 0.55 & & 339 & LSR & $15-19$ & 17.71 & 0.60 & & 309 \\
\hline PVS & $14-18$ & 15.86 & 0.75 & & 361 & PVS & $14-18$ & 15.88 & 0.72 & & 326 \\
\hline AVS & $17-23$ & 21.35 & 0.84 & & 363 & AVS & $18-24$ & 21.39 & 0.79 & & 329 \\
\hline
\end{tabular}

224

225

226

227

228

229

230 
bioRxiv preprint doi: https://doi.org/10.1101/716183; this version posted July 26, 2019. The copyright holder for this preprint (which was not certified by peer review) is the author/funder, who has granted bioRxiv a license to display the preprint in perpetuity. It is made available under aCC-BY 4.0 International license.

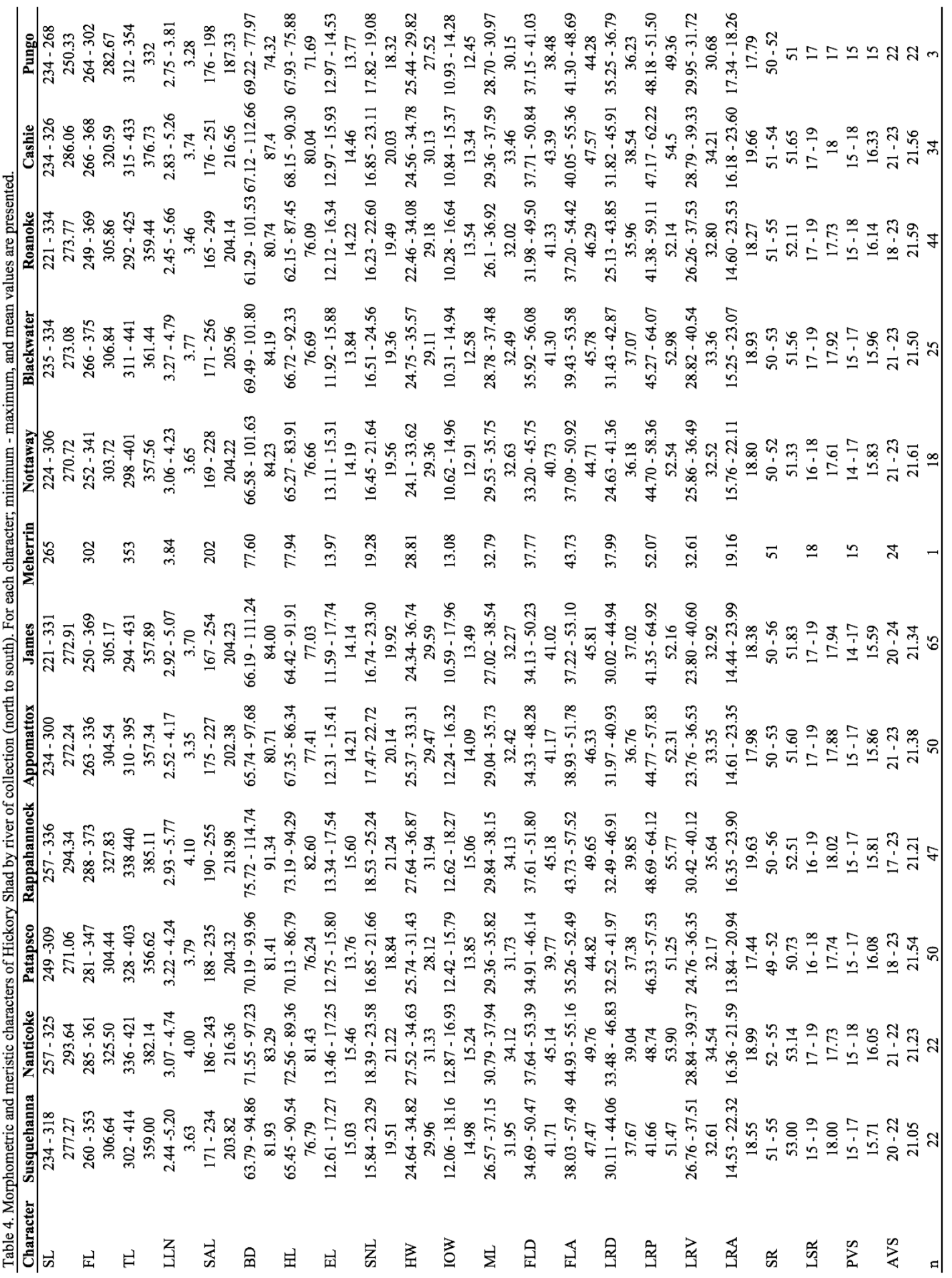


bioRxiv preprint doi: https://doi.org/10.1101/716183; this version posted July 26, 2019. The copyright holder for this preprint (which was not certified by peer review) is the author/funder, who has granted bioRxiv a license to display the preprint in perpetuity. It is made available under aCC-BY 4.0 International license.

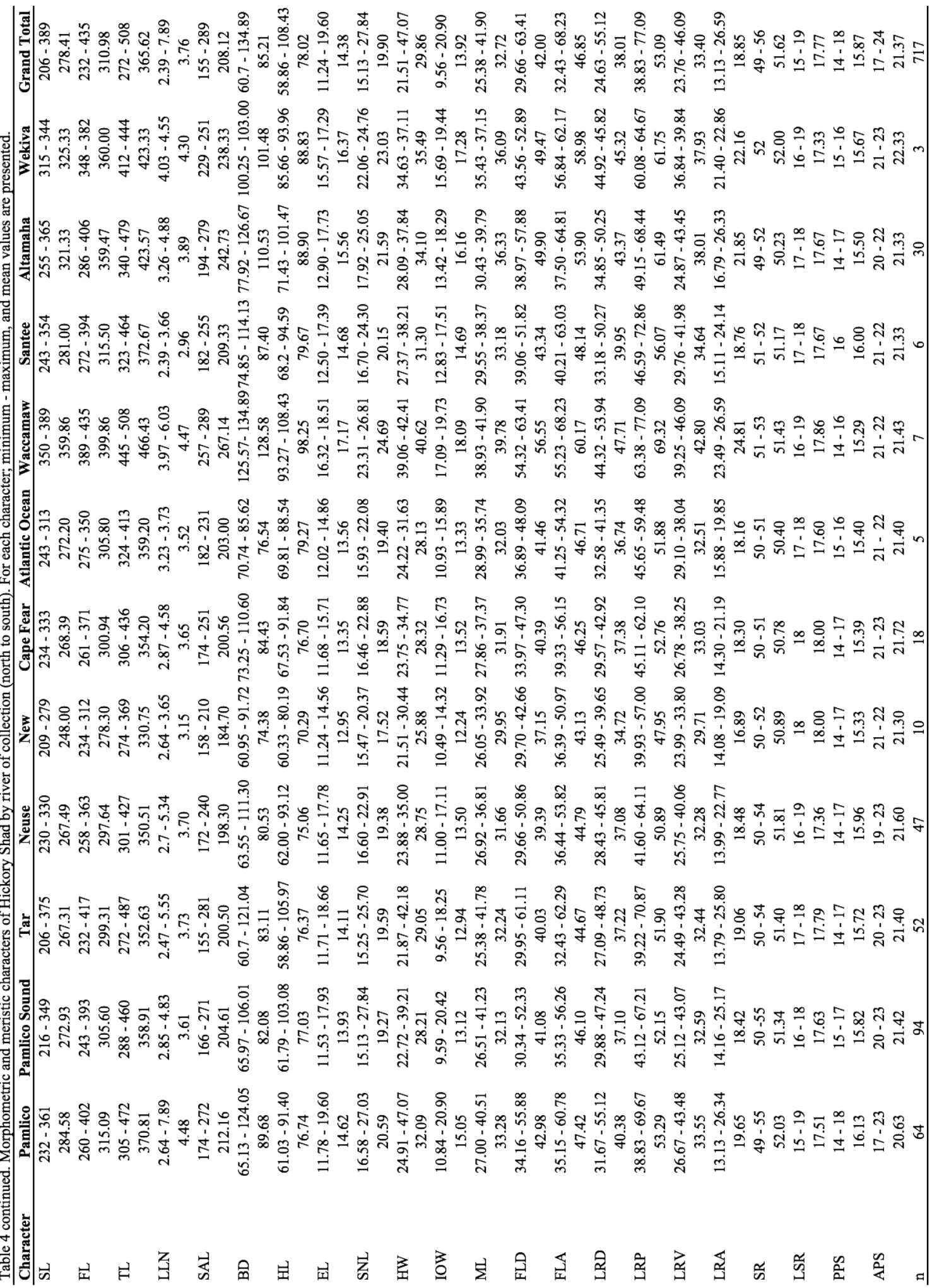


A basic review of the morphometric and meristic data showed sexual difference in many

236 characters, namely morphometric measurements. All morphometric characters showed sexual

237 difference in character means, yet some character differences were more substantial. For

238 example, the mean measurements (mm) of BD (Female: 91.44, Male: 79.03), FLD (Female:

239 63.41, Male: 39.77), SAL (Female: 218.99, Male: 197.51), and HL (Female: 81.40, Male: 74.72)

240 were largely different between sexes. For meristic counts on SR, LSR, PVS, and AVS there was

241 no observed difference between sexes and so the averages between males and females were

242 similar. Of the four counts, the largest difference in the averages was found for the count of LSR

243 where the averages were 17.81 and 17.71 for females and males, respectively. Due to the

244 differences in some characters (i.e., morphometric) by sex, it was necessary to divide the

245 morphometric and meristic data for males and females for accurate description and analysis.

247 Specimen Size

All Hickory Shad collected and included in this study were adults (sexually mature)

249 participating in the annual spawning run and all morphometric and meristic data reported are for

250 adult fish. Male specimens from locations combined ranged from 206 to $344 \mathrm{~mm}$ SL with a

251 mean \pm SD of $264.42 \pm 20.52 \mathrm{~mm}$. Female specimens ranged from 229 to $389 \mathrm{~mm}$ with a mean

252 of $289.72 \pm 24.71 \mathrm{~mm}$. Sizes for sexes and locations combined ranged from 206 to $389 \mathrm{~mm} \mathrm{SL}$

253 with a mean of $276.53 \pm 26.31 \mathrm{~mm}$. The linear relationships between FL and TL, and FL and SL,

254 were:

$$
\mathrm{TL}=1.169 * \mathrm{FL}+1.660\left(\mathrm{n}=705, \mathrm{r}^{2}=0.995\right) ; \text { and }
$$

$$
\mathrm{SL}=0.909 * \mathrm{FL}-4.274\left(\mathrm{n}=717, \mathrm{r}^{2}=0.992\right)
$$


The largest Hickory Shad were from the Waccamaw River, SC and the mean \pm SD was

$258 \quad 359.86 \pm 13.92 \mathrm{~mm}$ SL with a range between 350 and $389 \mathrm{~mm}$ SL; average weight was 1281.13

$259 \pm 95.46 \mathrm{~g}$ and all seven specimens from this river were female. On average the smallest Hickory

260 Shad were collected from the New River, NC with a mean \pm SD of $248 \pm 24.92 \mathrm{~mm}$ SL and a

261 range of 209 to $279 \mathrm{~mm}$ SL. However, the smallest Hickory Shad collected in this study (206

$262 \mathrm{~mm}$ SL) was a male from the Tar River, NC. Specimen total body weight $(\mathrm{n}=695)$ with sexes

263 and locations combined ranged from 206.03 to $1488.28 \mathrm{~g}$ with a mean \pm SD of $501.34 \pm 187.52$

$264 \mathrm{~g}$, and gonad weights $(\mathrm{n}=691)$ from 0.38 to $266.03 \mathrm{~g}$ with a mean of $49.88 \pm 45.78 \mathrm{~g}$.

Overall, females were larger than males of similar SL. The smallest male weighed 206.03

$268 \mathrm{~g}$ and largest weighed $866.50 \mathrm{~g}$. The smallest female weighed $242.40 \mathrm{~g}$ and largest $1488.28 \mathrm{~g}$.

269 Gonads for females weighed from 0.38 to $266.03 \mathrm{~g}$ with a mean \pm SD of $74.43 \pm 51.15 \mathrm{~g}$.

270 Gonads for males weighed from 0.90 to $62.53 \mathrm{~g}$ with a mean of $22.86 \pm 11.53 \mathrm{~g}$. Variation in

271 size and weight of female gonads were largely dependent on spawning status. Some gonad

272 specimens had deteriorated so gonad weight measurements $(n=4)$ and sex determination $(n=$

273 22) were not possible. In addition, the sexing of some specimens was omitted on the data sheet

274 during the examination process.

275

276 Missing data

277 Some of the 717 Hickory Shad could not be analyzed for the entire suite of 17

278 morphometric and four meristic characters due to specimen damage. This resulted in 146 missing

279 values across all morphometric and meristic characters. Missing value analysis was performed in 
280 SPSS version 24 [27] and the meristic character LSR had the most missing data (7.7\%). Of the

281 remaining characters only SR, LRA, and PVS had more than 1.0\% missing: 4.3, 1.3, and 1.1\%,

282 respectively. Values for count and percent missing of each character are reported in Table 5.

283

284

285

Table 5. Missing value analysis of 18 morphometric and four meristic characters of Hickory Shad.

\begin{tabular}{cccccc}
\hline & & & & \multicolumn{2}{c}{ Missing } \\
\cline { 3 - 6 } Character & $\mathrm{N}$ & Mean & Std. Deviation & Count & Percent \\
\hline SL & 717 & 278.41 & 27.69 & 0 & 0.0 \\
FL & 717 & 5.73 & 0.01 & 7 & 0.0 \\
TL & 710 & 5.89 & 0.01 & 3 & 0.4 \\
LLN & 714 & 1.31 & 0.14 & 1 & 0.1 \\
SAL & 716 & 5.33 & 0.02 & 1 & 0.1 \\
BD & 716 & 4.43 & 0.09 & 2 & 0.3 \\
HL & 715 & 4.35 & 0.03 & 3 & 0.4 \\
EL & 714 & 2.66 & 0.05 & 2 & 0.3 \\
SNL & 715 & 2.98 & 0.04 & 2 & 0.3 \\
HW & 715 & 3.39 & 0.04 & 2 & 0.3 \\
IOW & 715 & 2.62 & 0.07 & 3 & 0.4 \\
ML & 714 & 3.48 & 0.03 & 1 & 0.1 \\
FLD & 716 & 3.73 & 0.05 & 4 & 0.6 \\
FLA & 713 & 3.84 & 0.05 & 4 & 0.6 \\
LRD & 713 & 3.63 & 0.10 & 2 & 0.3 \\
LRP & 715 & 3.97 & 0.04 & 3 & 0.4 \\
LRV & 714 & 3.50 & 0.04 & 9 & 1.3 \\
LRA & 708 & 2.93 & 0.07 & 31 & 4.3 \\
SR & 686 & 51.62 & 1.17 & 55 & 7.7 \\
LSR & 662 & 17.77 & 0.58 & 3 & 0.4 \\
PVS & 709 & 15.86 & 0.73 & 0.81 & \\
AVS & 714 & 21.36 & & 3 & \\
\hline
\end{tabular}


Comparison between Hickory Shad and other Clupeids

290 values for morphologically similar clupeids, including the American Shad, Alewife, and

291 Blueback Herring (Table 6). Characters mentioned here represent the clearest difference between

292 species: Hickory Shad have a larger body depth as a percent of total length (22.31-26.55)

293 compared to American Shad (17.2-19.4) and Alewife (17.8-21.7), but body depth is similar to

294 that of Blueback Herring (22.1-25.2). The upper portions of the variable ranges for Hickory Shad

295 scute and scale row counts (PVS, AVS, and SR) were less than that for American Shad, but LSR

296 was greater for Hickory Shad. This is not surprising since the body depth as a percent of total

297 length was greatest for Hickory Shad, and the LSR character is counted along the depth of the

298 body. The range of interorbital width (IOW) as a percent of head length for Hickory Shad

299 (16.24-19.28) was most similar to Alewife (15.7-21.6); the range for American Shad (18.6-21.6)

300 was higher than for Hickory Shad but within the range for Alewife. Overall, Blueback Herring

301 interorbital width as a percent of head length (21.1-26.4) is the largest. As for eye length as a

302 percent of head length, the Hickory Shad has the smallest range (18.08-19.10), which is much

303 less than that of American Shad (27.3-32.0), Blueback Herring (23.4-30.0) and Alewife (26.9-

$30435.7)$ 
Table 6. Comparison of morphometric and meristic characters for Hickory Shad, American Shad, Alewife, and Blueback Herring. Range given for each, if available; usual values reported in literature in parentheses.

\begin{tabular}{lllll}
\hline Character & Hickory Shad & American Shad & Blueback Herring & Alewife \\
\hline BD \% TL & $22.31-26.55$ & $17.2-19.4^{\mathrm{a}}$ & $22.1-25.2^{\mathrm{a}}$ & $17.8-21.7^{\mathrm{a}}$ \\
HL \% TL & $21.34-21.64$ & $22.7-24.0^{\mathrm{a}}$ & $18.5-20.6^{\mathrm{a}}$ & $20.3-23.7^{\mathrm{a}}$ \\
EL \% HL & $18.08-19.10$ & $27.3-32.0^{\mathrm{a}}$ & $22.0-26.4^{\mathrm{a}}$ & $26.1-32.0^{\mathrm{a}}$ \\
SNL \% HL & $25.68-25.71$ & $26.9-32.0^{\mathrm{a}}$ & $23.4-30.0^{\mathrm{a}}$ & $26.9-35.7^{\mathrm{a}}$ \\
IOW \% HL & $16.24-19.28$ & $18.6-21.6 \mathrm{a}$ & $21.1-26.4 \mathrm{a}$ & $15.7-21.6 \mathrm{a}$ \\
FLA \% TL & $11.92-13.43$ & & & $10.3-12.0^{\mathrm{a}}$ \\
PVS & $14-18$ & $12^{\mathrm{b}}-19^{\mathrm{a}}$ & $12-16^{\mathrm{a}}$ & $12^{\mathrm{d}}-17^{\mathrm{f}}(14-15)^{\mathrm{a}}$ \\
AVS & $17-24$ & $19-25^{\mathrm{b}}$ & $18-21^{\mathrm{d}}$ & $17-21(19-20)^{\mathrm{a}}$ \\
SR & $49-56$ & $52-64^{\mathrm{c}}$ & $46-54^{\mathrm{d}}$ & $42^{\mathrm{d}}-54^{\mathrm{g}}$ \\
LSR & $15-19$ & $15-16^{\mathrm{d}}$ & $13-14^{\mathrm{e}}$ & $14^{\mathrm{d}}$ \\
\hline
\end{tabular}

${ }^{\mathrm{a}}$ Scott and Crossman 1973, ${ }^{\mathrm{b}}$ Hill 1956, ${ }^{\mathrm{c}}$ Walburg and Nichols 1967, ${ }^{\mathrm{d}}$ Hildebrand 1963

${ }^{\mathrm{e}}$ Thomson et al 197, ${ }^{\mathrm{f}}$ Leim and Scott $1966,{ }^{\mathrm{g}}$ Miller 1957

Discussion

It is often difficult to discern the causes of morphological and meristic variations between fish populations [22] though it is assumed they might be related to genetic differences or linked

310 to phenotypic plasticity resulting from non-homogeneous environmental factors in each river

311 [19]. However, reasons why there are variations in meristic and morphological characters were

312 not an objective of our study.

313 Instead, our study provides foundational information on the morphometric and meristic

314 variation of Hickory Shad across a large portion of the species range. To complement this study,

315 further research is needed to investigate these characters of Hickory Shad from more southern

316 rivers in Georgia and Florida. This would allow comparison of morphometric and meristic

317 variation across the entire species range and determine if greater geographic distance

318 corresponds to larger variation. It is more likely that adjacent rivers or watersheds share common

319 environmental characteristics compared to rivers separated by large distances, possibly leading to 
greater variation in morphometrics and meristics. For instance, we were able to obtain 22 samples from a small tributary of the Susquehanna, River Maryland at the mouth of Deer Creek (39.613358 N, -76.149024 W), which is near the northern end of the assumed Hickory Shad spawning range. Unfortunately, we were unable to obtain large sample sizes from the southernmost Hickory Shad spawning population of the St. Johns River, Florida, though we did obtain three specimens from the Wekiva River, a tributary of the St. Johns (28.8728226 N, 81.3689402 W). The Wekiva River, Florida, and Deer Creek, Maryland, are separated by roughly $1280 \mathrm{Km}$. not be collected. Attempts were made to have between 25-50 fish per watershed and a 50:50 sex ratio, but as with most all fisheries work, success in sampling is often not reliable. Multiple factors influenced our ability to collect more samples, including early Hickory Shad spawning runs in some locations, foul weather, low river water levels prohibiting boat access, severe longterm flooding, and expense of traveling to distant locations. It is possible that the morphometric

334 and meristic values presented here for rivers with small samples sizes may not accurately capture

335 the true natural variation of the characters in those populations. Additionally, the timing of

336 specimen collection was not standardized and often started after the spawning run had fully

337 begun, which could have potentially affected this study (i.e., size or sex distributions). Overall,

338 slightly more female specimens $(n=365)$ were collected than male $(n=330)$ representing $52.5 \%$ 339 and $47.5 \%$ of the specimens included in this study, respectively. The difference in the number of

340 males and females could be a product of gear bias and not necessarily representative of the

341 natural populations. For instance, gill nets used to collect some specimens in this study are more

342 selective for larger female Hickory Shad than smaller males. Melvin et al. [19] studying 
343 American Shad also found gill nets to be selective for larger females. Furthermore, we

344 experienced a willingness of sport fishers to provide specimens for our study, but reluctance to

345 provide females since most fishers wanted the roe for bait or for personal consumption.

347 Sexual Differences

348 Differences observed in the averages of morphometric characters when compared by sex

349 was not a surprising result and is relatively common in fish, though it has never been explicitly

350 described for Hickory Shad. This has significant implications and suggests studies on Hickory

351 Shad must be separated by sex and analyzed in that manner since there is substantial difference

352 between male and female specimens. Melvin et al. [19] came to similar conclusions for

353 morphometric and meristic characters of American Shad and so males and females were

354 analyzed separately.

356 Specimen Size

357 It is important to note that the morphometric measurements presented in this study are of

358 frozen and not freshly caught Hickory Shad. It is possible that the freezing and thawing process

359 may slightly alter the shape and or size of some morphometric characters. Melvin et al. [28]

360 reported a significant difference $(\mathrm{P}<0.01)$ between length measurements of live American Shad

361 in the field compared to measurements of dead specimens in the laboratory. In the event

362 American Shad were frozen prior to measurement, the length was multiplied by 1.021 to better

363 approximate fresh length [28]. Though fish samples are often frozen by biologists for later

364 processing, future studies should investigate if there is a significant difference between

365 morphometric measurements for fresh versus frozen Hickory Shad and, if so, which 
measurements are the most robust to the freezing and thawing process. Cronin-Fine et al. [29]

367 found 10 geometric morphometric measurements of Alewife that did not have a significant

368 difference between fresh and frozen specimens. Generally for meristics, the act of freezing and

369 thawing is not problematic since it does not change the counts of meristic features.

371 similar to morphometric measurements, the bias is shared across all individuals. Also, gonad

372 weight can be extremely dependent on spawning status (pre or post-spawn), especially for

373 females. Spent females weigh less than ripe and ready-to-spawn individuals, but unfortunately

374 spawning status was not recorded during dissections. There were a few instances of gonads that

375 were unable to be weighed (or sexed) because they were no longer intact or starting to

376 decompose. This was likely a result of freezer storage for an extended length of time, multiple

377 freezing and thawing events, or the length of time from collection till initial freezing. This was

378 not a serious problem; 26 specimens exhibited deterioration and this state was relatively random

379 across rivers. Also, it was likely that some of the individuals not sexed was caused by human

380 error instead of relating to the state of the gonads.

381 The regression equations for relationships between Hickory Shad FL and TL, and

382 between FL and SL, provide a means for converting between the various measurements of fish

383 size. This could be useful for biologists or fishery managers to accurately estimate one length

384 from another in the instance that only one of the measurements was recorded.

Missing Data

Though not a frequent problem in this study, missing data are quite common in

388 morphometric (and meristic) studies [30]. Some of the specimens could not be analyzed for the 
entire 17 morphometric and four meristic characters due to damage including broken or missing

390 fins, missing scales, and wounds from predation or gear-related injury. Missing scales are not

391 surprising, since the Hickory Shad as well as other clupeids are very susceptible to shedding

392 scales. The frequency of missing values for all characters can be found in Table 5. In our study

393 no imputation procedures (i.e., replacement or regression-based approaches) were used to

394 estimate missing data; instead these values were simply omitted.

Comparison between Hickory Shad and other Clupeids

Most of the morphometric and meristic characters investigated in this study do not serve careful examination of certain characters can help narrow down the species. One common and definitive way to distinguish Hickory Shad from the other species is by gill raker counts. Though

401 not directly incorporated into this study, a random subset of Hickory Shad specimens was analyzed for gill raker counts. It was determined that Hickory Shad had between 19-22 gill

403 rakers on the lower limb of the first arch $(n=463)$, which is considerably less than the other

404 anadromous Alosa species. American Shad typically have 59-76 lower gill rakers on the first 405 arch, Blueback Herring 41-52, and Alewife 38-46, all of which are higher counts [31] due to 406 their diet being different than Hickory Shad, which are more piscivorous [32].

\section{Conclusion}

410 and the intent of our study was to expand the existing taxonomic knowledge of the species.

411 Mitchill [2] used six meristic characters in describing the species: branchiostegal, pectoral, 
412 ventral, anal, dorsal, and caudal rays. These six characters were not included in this study

413 because the methods Mitchill used to count them were not available and therefore no direct

414 comparison was possible. Instead, 17 morphometric measurements and four meristic counts not

415 included in the original description of the species were utilized. The information about the

416 anatomical characteristics presented herein are lacking in the literature, though they are well

417 known for most other anadromous fish species. These additional morphological and meristic

418 characters may prove valuable for separating regions or watersheds in future studies. Geometric

419 morphometric analysis may be another viable option to investigate body shape variability. In

420 addition, there still remain many unanswered questions regarding Hickory Shad life history,

421 biology, and stock status that should be addressed so that the species can be properly managed

422 and all spawning populations sustained. Furthermore, the intraspecific variation of Hickory Shad 423 described here could be used to discriminate the different populations using multivariate analysis

424 [33].

426 Acknowledgments

427 We thank the North Carolina Wildlife Resources Commission for providing funding through the 428 Sport Fish Restoration Act. We also thank the many agencies that collected samples: North

429 Carolina Wildlife Resources Commission, North Carolina Division of Marine Fisheries, South

430 Carolina Department of Natural Resources, Florida Fish and Wildlife Conservation Commission,

431 Virginia Department of Game and Inland Fisheries, Maryland Department of Natural Resources,

432 Georgia Department of Natural Resources, Delaware Division of Fish and Wildlife, and the

433 Smithsonian Environmental Research Center. The Department of Biology at East Carolina

434 University provided logistic support, travel, and field and laboratory equipment. 
Conceptualization: Roger A. Rulifson

Data curation: Roger A. Rulifson

439 Formal analysis: Jordan P. Smith; Michael W. Brewer

440 Funding acquisition: Roger A. Rulifson.

441 Investigation: Jordan P. Smith

442 Methodology: Jordan P. Smith, Michael W. Brewer, Roger A. Rulifson

443 Project administration: Roger A. Rulifson.

444 Resources: Roger A. Rulifson.

Software: Jordan P. Smith

446 Supervision: Roger A. Rulifson, Michael W. Brewer

447 Visualization: Jordan P. Smith

448 Writing - original draft: Jordan P. Smith

449 Writing - review \& editing: Roger A. Rulifson, Michael W. Brewer, Jordan P. Smith

\section{References}

1. Gill TN. Report in part of Samuel L. Mitchill on the fishes of New York. Washington, D. C. 1898.

2. Mitchill SL. Report, in part, on the fishes of New-York. Trans. Lit. Phil. Soc. NY. 1814:450.

3. Regan CT. XXVI. - A revision of the Clupeoid fishes of the genera Pomolobus, Brevoortia and Dorosoma, and their allies. Annals and Magazine of Natural History. 1917; 19:112, 297 316; DOI: 10.1080/00222931709486942.

4. Bowen, BR, Kreiser BR, Mickle PF, Schaefer JF, Adams SB. Phylogenetic relationships among North American Alosa species (Clupeidae). J Fish Biol. 2008; 72:1188-1201.

5. Bailey RM, Winn HE, Smith CL. Fishes from the Escambia River, Alabama and Florida, with ecologic and taxonomic notes. Proc Acad Nat Sci Philadelphia. 1954; 56:109-164.

6. Svetovidov AN. Systematics of North American anadromous Clupeoid fishes of the genera Alosa, Caspialosa, and Pomolobus. Copeia 1964:118-130.

7. Mansueti RJ. Eggs, larvae, and young of the Hickory Shad, Alosa mediocris, with comments on its ecology in the estuary. Ches Sci. 1962; 3:1733-205. 
8. Perillo JA, Butler LH. 2009. Evaluating the use of Fairmount Dam fish passage facility with application to anadromous fish restoration in the Schuylkill River, Pennsylvania. J Penn Acad Sci. 2009; 83(1):24-33.

9. Harris, JE, McBride RS, Williams RO. Life history of Hickory Shad in the St. Johns River, Florida. Trans Am Fish Soc. 2007; 136(6):1463-1471.

10. Hildebrand SF, Schroeder WC. Fishes of Chesapeake Bay. US Bur Fish Bull. 1928; Vol 18 Part 1:388 p.

11. Rulifson RA. 1994. Status of anadromous Alosa along the east coast of North America. In: Cooper JE, Eades RT, Klauda RJ, Loesch JG, editors. Anadromous Alosa Symposium. Tidewater Chapter, American Fisheries Society, Bethesda, MD. 1994:134-158.

12. Murauskas JG, Rulifson RA. 2011. Reproductive development and related observations during the spawning migration of hickory shad, Alosa mediocris. Trans Am Fish Soc 2011; 140(1):1035-1048.

13. Uhler PR, Lugger O. Report of the Commissioners of Fisheries of Maryland. Annapolis, MD. 1876:159-160.

14. Jordan DS, Evermann BW. 1896. The Fishes of North and Middle America, Smithsonian Institution, US Nat. Mus., Washington. 1896; 1:425-426.

15. Smith HM. The fishes of North Carolina. EM Uzzell \& Company. 1907; Vol 2.

16. Jones PW, Martin FD, Hardy JD, Jr. Development of fishes of the Mid-Atlantic Bight: an atlas of egg, larval and juvenile stages: Vol 1 Acipenseridae through Ictaluridae. US Fish Wildl Serv. 1978.

17. Smith CL. The inland fishes of New York State. NY State Dep Envir Cons, Albany, NY. 1985.

18. Menhinick EF. Freshwater fishes of North Carolina. NC Wildlife Resources Commission, Raleigh. 1991.

19. Melvin GD, Dadswell MJ, McKenzie JA. Usefulness of meristic and morphometric characters in discriminating populations of American shad (Alosa sapidissima) (Ostreichthyes:Clupeidae) inhabiting a marine environment. Can. J. Fish. Aquat. Sci. 1992; 49:266-280.

20. Rulifson RA, McKenna SA, Gallagher M. Tagging studies of striped bass and river herring in upper Bay of Fundy, Nova Scotia. NC Dep. Nat. Res. Comm. Develop., Div. Mar. Fish., Morehead City. 1987.

21. Swain DP, Foote CJ. Stocks and chameleons: the use of phenotypic variation in stock identification. Fish. Res. 1999; 43:113-128.

22. Cadrin SX. Advances in morphometric identification of fishery stocks. Rev Fish Biol Fisheries. 2000; 10:91-112.

23. Siddik MAB, Hanif MA, Chaklader MR, Nahar A, Fotedar R. A multivariate morphometric investigation to delineate stock structure of gangetic whiting, Sillaginopsis panijus (Teleostei: Sillaginidae). SpringerPlus. 2016;5:520.

24. Hubbs CL, Lagler KF. Fishes of the Great Lakes Region. Ann Arbor: The University of Michigan Press. 1947.

25. Smith CM, Rulifson RA. Overlapping habitat use of multiple anadromous fish species in a restricted coastal watershed. Trans Am Fish Soc. 2015; 144(6):1173-1183.

26. Nichols PR. Comparative study of juvenile American Shad populations by fin ray and scute counts. US Department of Interior, US Fish Wildl Serv, Bur Comm Fish Spec Scient RepFish. No. 525. 1966. 
27. Melvin GD, Dadswell MJ, Martin JD. Impact of lowhead hydroelectric tidal power development on fisheries: 1, a pre-operation study of the spawning population of American Shad, Alosa sapidissima (Pisces: Clupeidae), in the Annapolis River, Nova Scotia, Canada. Dep. Fish. Oceans, Fish. Res. Branch, Fish. Envir. Sci. Div., Biological Station. 1985.

28. IBM Corporation. SPSS Statistics for Windows, Version 24.0. Armonk (NY): IBM; 2016.

29. Cronin-Fine L, Stockwell JD, Whitener ZT, Labbe EM, Willis TV, Wilson KA. Application of morphometric analysis to identify alewife stock structure in the Gulf of Maine. Mar Coast Fish. 2013; 5(1):11-20.

30. Clavel J, Merceron G, Escarguel G. Missing data estimation in morphometrics: how much is too much? Syst Biol. 2014; 63(2)203-218.

31. Hildebrand SF. Family Clupeidae. Pages 314-331 In: Fishes of western North Atlantic. Sears Found. Mar. Res. Mem. 1963; 1(3).

32. Greene KE, Zimmerman JL, Laney RW, Thomas-Blate JC. 2009. Atlantic coast diadromous fish habitat: A review of utilization, threats, recommendations for conservation, and research needs. Atlantic States Marine Fisheries Commission, Washington, DC. Habitat Management Series No. 9.

33. Smith JP. Hickory Shad Alosa mediocris (Mitchill) stock identification using morphometric and meristic characters. MS thesis, East Carolina University, Greenville, NC. 2017.

34. Whitehead PJP. Food and Agriculture Organization species catalogue, volume 7, clupeoid fishes of the world (suborder Clupeoidei), part I: An annotated and illustrated catalogue of the herrings, sardines, pilchards, sprats, shads, anchovies and wolf-herrings (Chirocentridae, Clupeidae and Pristigasteridae). FAO Fish Synopsis 1985; No. 125: 1-303. 
bioRxiv preprint doi: https://doi.org/10.1101/716183; this version posted July 26, 2019. The copyright holder for this preprint (which was not certified by peer review) is the author/fundes who-has-granted biofxiv a license to display the preprint in perpetuity. It is made available und

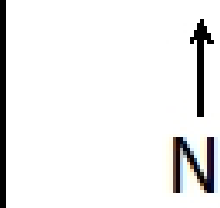

$\uparrow$

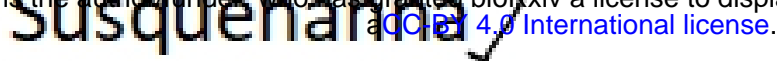

Susquenahidal

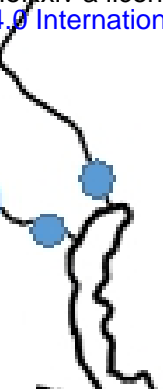

Rappahannock Appomattox Patapsco

Roanoke

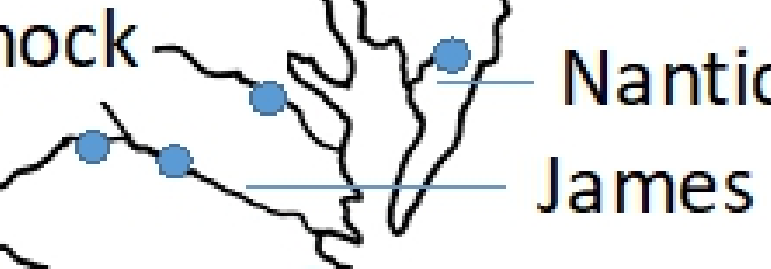

Nanticoke

James

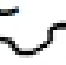

Cape Fear

Waccamaw

Altamaha

\section{Atlantic Ocean}

St. Johns

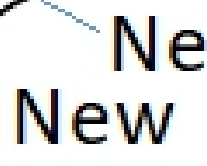

Blackwater

Santee

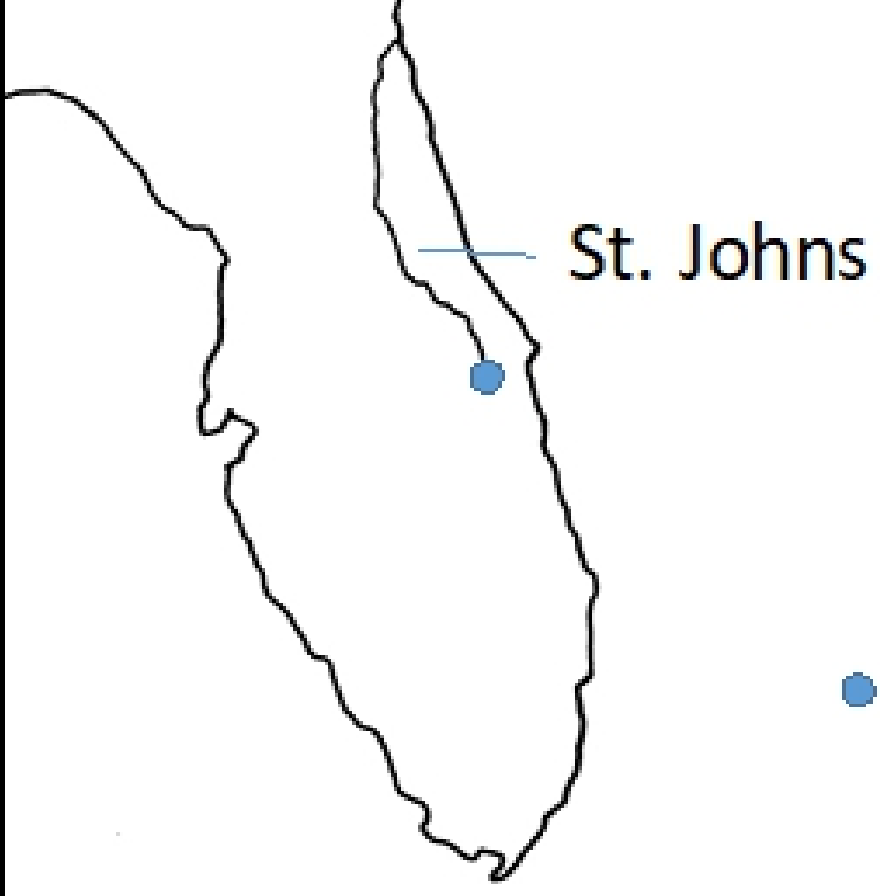

Nottoway

Cashie

Tar-Pamlico

Neuse

- Collection Sites 


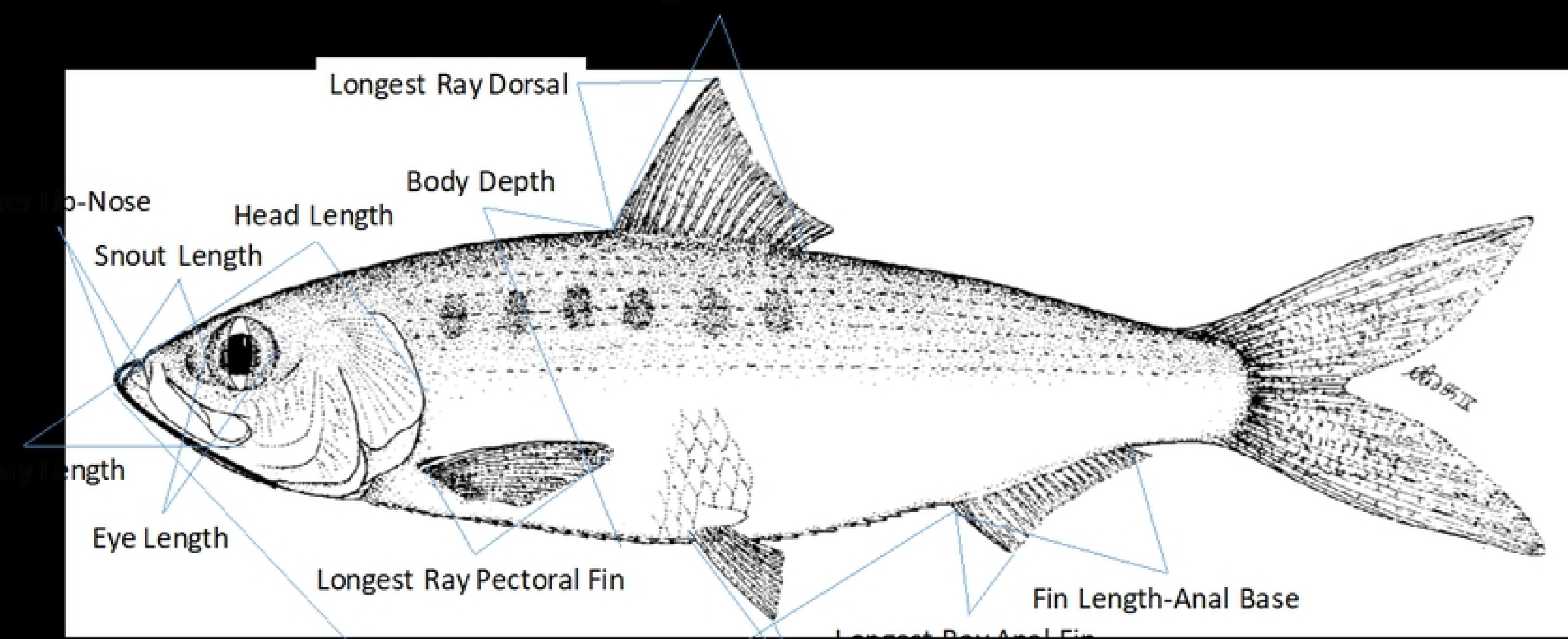

Figure 